\title{
REVIEW
}

\section{Jadeite and jadeitite-bearing rock in the Sanbagawa and the Kamuikotan belts, Japan: A review}

\author{
Takao HiRAJIMA \\ Department of Geology and Mineralogy, Graduate School of Science, Kyoto University, Kyoto 606-8502, Japan
}

\begin{abstract}
The mode of occurrence of jadeitic pyroxenes and their origins were reviewed using literatures published in the Sanbagawa belt (sensu lato), SW Japan, and the Kamuikotan belt, Hokkaido. Jadeite + quartz assemblage is found from tectonic blocks both in the Yorii area of the Kanto Mountains in the Sanbagawa belt and the Kamuikotan Gorge area, and its formation timing is predated to the main metamorphism in each area, where albite is stable along with metamorphic pyroxenes with lower jadeite contents (namely $\mathrm{Jd}_{<50}$ ). The jadeite + quartz assemblage is recently found as inclusions in garnet grains in some rocks with peculiarly lower $\mathrm{CaO}$ and/ or $\mathrm{MgO}$ bulk compositions, which suffered the eclogite facies metamorphism in the Sanbagawa belt of Shikoku area, although it is not detected from the matrix of the eclogite facies rocks. Recent zirconology applied to the jadeite + quartz rock in the Yorii area causes a hot argument on its origin, i.e., the wholesale metasomatic replacement origin or the vein precipitation origin. In either case, this methodology gave new insight on fluid activity recorded in Jurassic or post-Jurassic subduction zone.
\end{abstract}

Keywords: Jadeite, Sanbagawa, Kamuikotan, Mesozoic, Japan

\section{INTRODUCTION}

The jadeite + quartz assemblage is one of the diagnostic assemblages in metamorphic rocks formed under the eclogite-facies and the lawsonite-jadeite blueschist facies (e.g., Hacker et al., 2003). Therefore the identification of this assemblage has a paramount importance not only to elucidate the developing history of the high-pressure (HP) type metamorphic belts (e.g., Miyashiro, 1965, 1973) but also to understand the mass circulation in the subduction zone (e.g., Hacker et al., 2003).

During the last decade, $\mathrm{U}-\mathrm{Pb}$ dating and the rare earth element (REE) concentration of zircon grains, so called zirconology newly developed in $21^{\text {st }}$ century, can shade a light to discuss the origin of jadeitite and the fluid activity in the subduction/collision system (e.g., Tsujimori and Harlow, 2012; Harlow et al., 2015). A hot argument on the origin of jadeitite has been done among two schools; 1) the wholesale metasomatic replacement and 2) the vein precipitation (e.g., Yui et al., 2010; Tsujimori and Harlow, 2012; Harlow et al., 2015). These two mechanisms imply contrasting chemical cycling paths for elements such as

doi:10.2465/jmps. 170409

T. Hirajima, hirajima@kueps.kyoto-u.ac.jp Corresponding author
$\mathrm{Al}, \mathrm{Na}, \mathrm{Zr}$, and $\mathrm{Hf}$ in subduction zones, which in turn should result from different physiochemical conditions.

This article aims to overview jadeite-bearing rocks from the Sanbagawa (sensu lato) and the Kamuikotan belts on the abovementioned context.

\section{Brief overview of the Sanbagawa belt (sensu lato)}

The recent data accumulation of detrital zircon ages from metasedimentary rocks of so-called 'Sanbagawa belt' has brought reconsideration of subdivision of the belt; see the review by Itaya et al. (2011). In this paper, we use the term 'Sanbagawa belt' in the broad sense; i.e., the Sanbagawa belt (sensu lato) includes so-called Sanbagawa schist, Mikabu greenstone complex and associated lowgrade HP rocks in the Northern Chichibu belt.

The Sanbagawa schist and the Northern Chichibu belts stretch through SW Japan over a length of 800 $\mathrm{km}$ from the Kanto Mountains in the eastern end, through Chubu district and Kii peninsular in Honshu, and Shikoku, to Saganoseki Peninsular, Kyushu, in the western end (Fig. 1). The Mikabu greenstone complex is sporadically exposed between the Sanbagawa schist and the Northern Chichibu belt from the Kanto Mountains to the western Shikoku. 


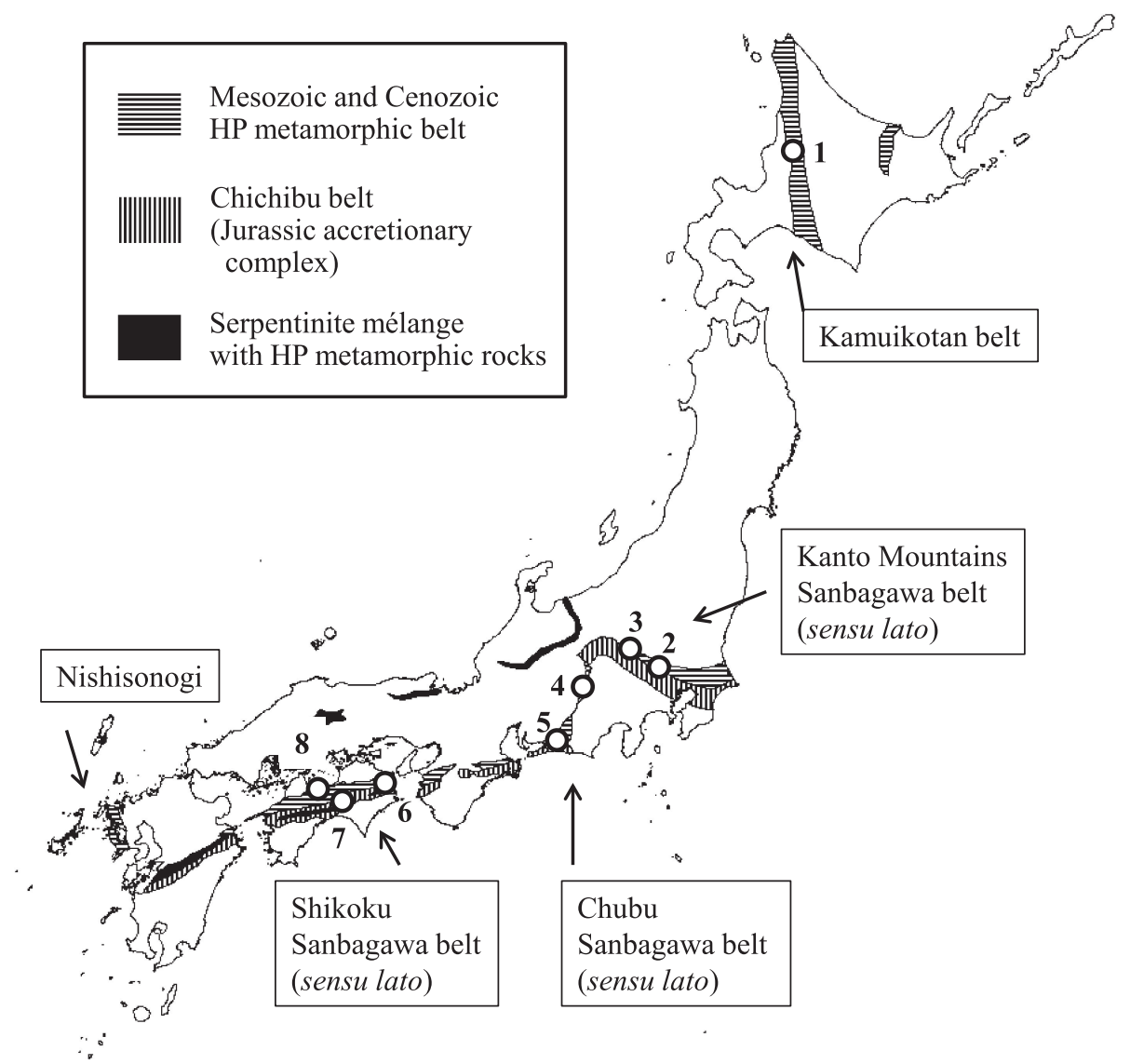

Figure 1. The localities of jadeitebearing rocks in the Sanbagawa (sensu lato) and the Kamuikotan belts. 1. The Kamuikotan gorge, Hokkaido; 2. Yorii, Saitama; 3. Shimonita, Gunma; 4. Oshika, Nagano; 5. Shibukawa, Shizuoka; 6. Bizan, Tokushima; 7. Ananai, Kochi; 8. Besshi, Ehime.
The Sanbagawa belt suffered subduction related high $P / T$ type metamorphism at East Asian margin in Cretaceous (e.g., Itaya et al., 2011, other references therein). The protolith of the Sanbagawa schist and the Northern Chichibu belt formed by the accretion of ocean floor materials and trench-fill sediments, but their sedimentation timing is different, such as Cretaceous for the Sanbagawa schist (Tsutsumi et al., 2009; Aoki et al., 2011) and from Permian to the earliest Cretaceous for the Northern Chichibu belt (Matsuoka et al., 1998). The Mikabu greenstone complex is mainly composed of metabasic rocks derived mainly from gabbro, pillow lava and volcani clastic sediments and minor amounts of ultramafic rocks, chart and pelitic rocks.

Based on the mode of occurrence of the diagnostic metamorphic minerals in metapelite, the Sanbagawa schist is subdivided in to three mineral zones, from chlorite, garnet and biotite zones with the increasing grade of the metamorphism (e.g., Kurata and Banno, 1974; Enami, 1983, Banno and Sakai, 1989; Higashino, 1990). The metamorphic zoning has also been defined by the mineral assemblages in mafic schists from pumpellyite-actinolite to the epidote-amphibolite facies (e.g., Nakajima et al., 1977; Otsuki and Banno, 1990). The eclogite facies rocks are distributed in the higher grade zone in central and eastern Shikoku, and possibly in Kii peninsular (e.g., Kunugiza et al., 1986; Wallis and Aoya, 2000; Aoya, 2001).

Both the Nagasaki and Nishisonogi metamorphic complexes in the Western Kyushu have been considered as an extension of the Sanbagawa belt (Fig. 1). The detail review on the jadeitite in the Nishisonogi complex refers Nishiyama et al. in this issue.

\section{Jadeite-bearing rocks in the Kanto Mountains of the Sanbagawa belt}

Titibu-Hisui. In the Kanto Mountains, so called 'TitibuHisui (jade)' has been known as precious stones excavated from some remains of the Heian (794-1185 AD) or much older periods, but most of them are 'nephrite jade' consisting of actinolite and tremolite (e.g., Sakurai and Nagashima, 1957; Hayashi et al., 2013). Even in the present day, Titibu-Hisui can be collected in the upper stream of Misawa river, probably derived from some serpentinite bodies in the Sanbagawa schist or the Mikabu greenstone complex. The following description will concentrate on jadeite or omphacite-bearing rocks associated with or without quartz in the Kanto Mountains. 
The jadeite study before EPMA age. The first identification of jadeite was done by means of the optical microscopy and the X-ray diffraction (XRD) method in the eastern part of the Kanto Mountains through the campaign of the zonal mapping of the relevant area by Seki $(1958,1960)$. Seki $(1958)$ divided the study area in to six mineral zones from zone 1) to 6) with the progressive mineral changes; such as 1) for un-metamorphosed zone, 2), 3), and 5) for pumpellyite dominant zones, 4) for lawsonite appearance zone and zone 6) for epidote garnet zone. Subsequently, Seki (1960) reported the occurrence of jadeite from the zone 4), mainly corresponding to a part of the Mikabu greenstone complex. Based on the mode of occurrence of those diagnostic minerals of the glaucophane schist facies, Seki (1960) pointed out that his zone 4) showed the highest $\mathrm{P} / \mathrm{T}$ gradient in the Kanto Mountains (Fig. 3A of Seki, 1960). Subsequently, his works were cited as an example of typical glaucophane schist facies metamorphism in Japanese Island by Miyashiro's text books (Miyashiro, 1965, 1973), i.e., the pressure type of the Sanbagawa metamorphism in the Kanto Mountains had been regarded as higher than the rest of the Sanbagawa belt.

After Seki's pioneering work, jadeite and omphacite were found from five areas in the Kanto Mountains, 1) jadeite from an albitite in the Kanasaki (Kanagasaki) area (Seki, 1961), 2) omphacite veins in metadiabase from the Mikabu greenstone complex in the Asahine area (Hashimoto, 1964), 3) pebbles of jadeitic pyroxenes found from sandstone beds in the Sanchu graben with lower Cretaceous age (Seki, 1965), 4) jadeite and omphacite, not associated with quartz, in meta-basalts from the Mikabu greenstone complex in the Shimonita area (Tanabe et al., 1982; Arai et al., 2011) and 5) Jadeite + quartz assemblage in a leucocratic tectonic block exposed at the unit boundary between the Sanbagawa schist and the Tochiya Formation, the latter could be the member of the Atokura nappe (Hirajima, 1983a).

Jadeite from albitite (Seki, 1961) and omphacite in the monomineralic vein (Hashimoto, 1964) should be originated closely related to aqueous fluid, although subsequent modern petrological studies using EPMA and/or ICP-MS have not been done for these rocks.

The finding of detrital jadeite grains from the Sanchu graben with Hauterivian to Turonian fossils, i.e., 135.0-88.5 Ma, as well as the previous discovery of lawsonite and pumpellyite-bearing rocks as clastic materials in the same horizon could be interpreted that the Sanbagawa metamorphism of the Kanto Mountains must have occurred before the deposition of lower Cretaceous formation (Seki, 1965).

The geochronological studies on the Sanbagawa schist in the Kanto Mountains suggest K-Ar phengite ages from 90-60 Ma (Hirajima et al., 1992; Miyashita and Itaya, 2002) and the youngest detrital zircon SHRIMP ages from 95-79 Ma with 13 May older age than the $\mathrm{K}-$ Ar phengite age in each sample (Tsutsumi et al., 2009). Therefore, the Sanbagawa belt is unlikely for the provenance of the jadeite grains found in the Sanchu graben, and the identification of source region of those $\mathrm{H} P$ minerals remains as a future problem.

Jadeite identification using EPMA; a) Jadeitearagonite rocks in the Shimonita area. Tanabe et al. (1982) found jadeite-aragonite assemblage from metavolcanics in the Mikabu greenstone complex of the Shimonita area, located in the western extremity of the Kanto Mountains. This is the first report of metamorphic aragonite and the first confirmation of jadeite done by EPMA in the Sanbagawa belt. The meta-volcanics include both pillow lavas and massive varieties, and they are characteristically lack distinct schistosity in contrast with the surroundings, mainly composed of schistose actinolite rocks (Arai et al., 2011).

Jadeite-bearing meta-volcanics are completely recrystallized and free from any igneous minerals: The rock matrix is mainly composed of jadeite, taramite/magnesiokatophorite, phengite, green-colored biotite, pumpellyite, albite, epidote, chlorite, apatite and titanite with/without aragonite and/or calcite. The vesicles of pillow basalts are completely filled by jadeite, taramite, titanite, muscovite, green-colored biotite, chlorite, albite and aragonite/calcite with/without andradite. Generally jadeite grains show dark-green color in their core with higher aegirine component, and do pale-green to colorless in their rim with lower aegirine component (Fig. 2; Fig. 5B of Arai et al., 2011). Later stage omphacite/aegirine-augite and glaucophane are identified at the rim of jadeite and taramite/magnesiokatophorite grains. Quartz was not detected from those jadeite-bearing rocks.

Tanabe et al. (1982) concluded that those rocks are tectonic blocks in the Mikabu greenstone complex, because they did not detect jadeite and aragonite from the surroundings.

Arai et al. (2011) pointed out the jadeite-aragonite bearing meta-basaltic lavas, along with jadeite-free pargasite rocks and jadeite-free garnet epidote rocks, are embedded as blocks/lenses in the matrix mainly composed of the actinolite rock. They also reported that the actinolite rock is mainly composed of actinolite, chlorite and albite along with epidote, pumpellyite and omphacite with lower jadeite content ( $\mathrm{Jd}_{<50}$; Fig. 2).

The observed block-in-matrix structure is generally one of the characters of the tectonic mélange. However, Arai et al. (2011) did not apply this idea, because of the 


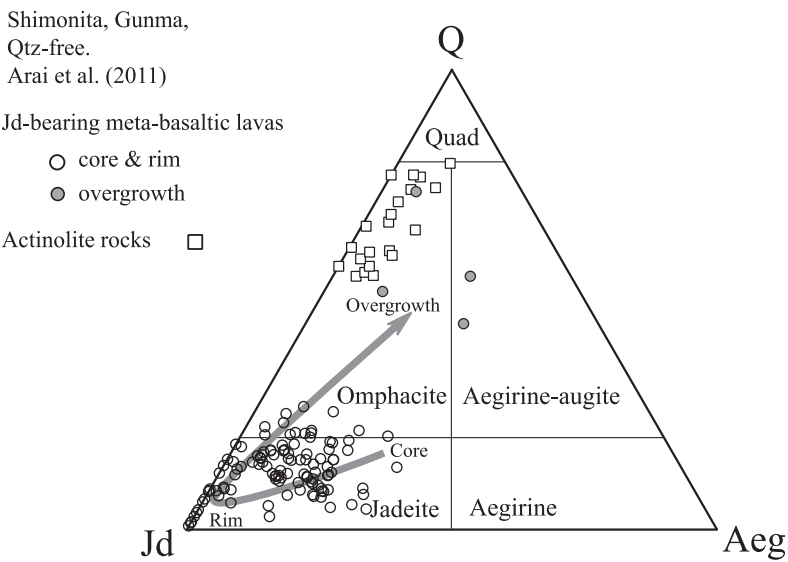

Figure 2. Na-pyroxene compositions in metabasites of the Shimonita area, NW Kanto Mountains (modified from Fig. 5B of Arai et al., 2011).

lack of the common deformation structure seen in the tectonic mélange, and the similarity of the concentrations of high field strength elements of the jadeite-bearing metavolcanics ( $\sim 10 \mathrm{wt} \% \mathrm{Na}_{2} \mathrm{O}$ in bulk composition) to oceanic island basalts (OIBs) in the Mikabu greenstone complex of Shikoku, and those of relict $\mathrm{Ca}$-pyroxenes in the actinolite rock to thoreiitic MORB in the Mikabu greenstone complex of the Kanto Mountains. Finally, they concluded that the jadeite-bearing meta-basaltic rocks suffered a Na-enrichment event before the Sanbagawa metamorphism and then jadeite grew during the HP metamorphism.

Jadeitic and omphacitic pyroxenes not associated with quartz do not manifest the high pressures, which normally attributed to silica-saturated or oversaturated rocks (e.g., Fig. 3). Suzuki and Ishizuka (1998) reported the metamorphic aragonite from the metabasite in the Mikabu greenstone complex of the Shikoku area. Therefore, aragonite and jadeite not associated with quartz can be stable under the albite stable condition of the Sanbagawa metamorphism.

In either case, appropriate geochronological study for jadeite-bearing rocks is indispensable to conclude the origin of jadeite in the Shimonita area.

Jadeite identification using EPMA; b) Jadeite + quartz rock in the Yorii area. Hirajima (1983a) found a leucocratic rock with the jadeite + quartz assemblage from an unexpected geologic unit in the Yorii area, the eastern part of the Kanto Mountains, i.e., the Tochiya Formation, which could be the member of the Atokura nappe and overlaid to the Sanbagawa belt. The main block of the leucocratic rock, $5 \times 5 \times 10 \mathrm{~m}$, exists at the top of the small hill of the terrane of the Tochiya Formation near the boundary with the Sanbagawa schist and the similar rock is exposed $\sim 30 \mathrm{~m}$ in length. The

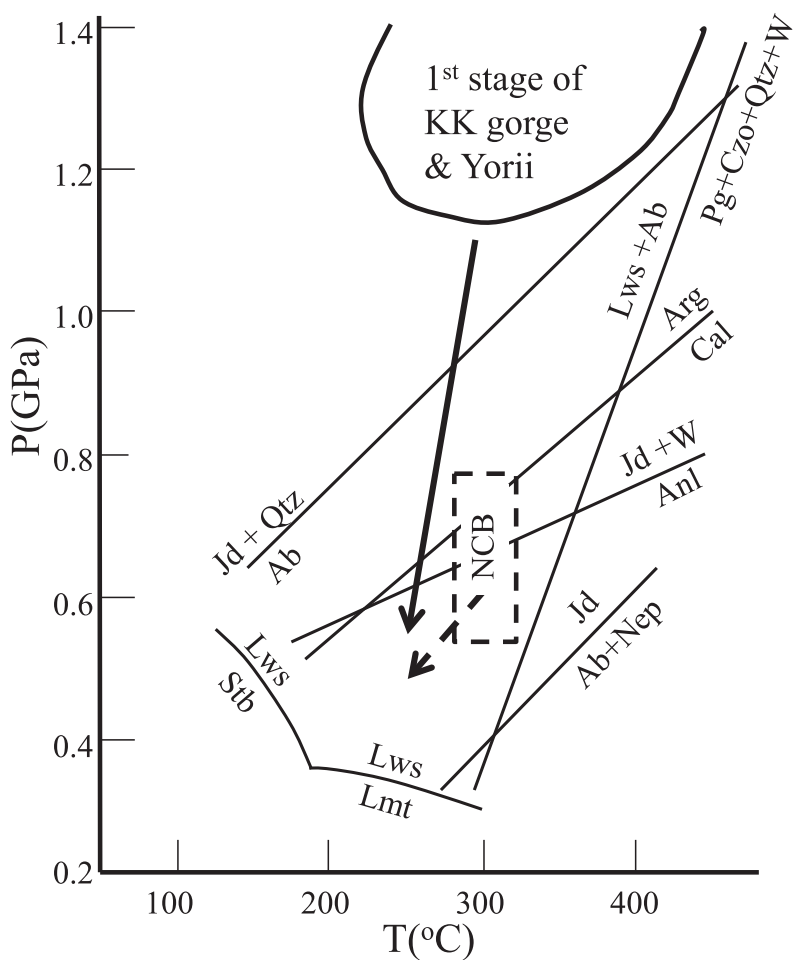

Figure 3. The stability field of jadeite (Jd) with/without quartz (Qtz). The transition from stilbite/laumontite (Stb/Lmt) to lawsonite (Lws) in the CASH system from Nitsch (1968) and Liou (1971a, 1971b). Other reaction curves are calculated using database of Holland and Powell (1998). Pg, paragonite; Czo, clinozoisite; W, $\mathrm{H}_{2} \mathrm{O}$. Solid arrow, $P T$ path of the jadeite + quartz rock in the Yorii area and Kamuikotan (KK) gorge (Takayama, 1986: Osada et al., 2007). Broken arrow, $P T$ path of jadeitebearing rocks in the Ananai area, Kochi, in the Northern Chichibu belt (NCB: Endo, 2015).

close association of the leucocratic rock and serpentinite may suggest the tectonic block origin of those rocks, although the clear contact relationship between the leucocratic rocks and the surroundings is not found.

The leucocratic rock shows grayish-white color for unaided eyes along with blue glaucophane veins and colorless quartz veins. The rock matrix is mainly composed of equigranular quartz aggregates and jadeite + albite aggregates with 3-5 mm in diameter. Jadeite generally occurs as blade/columnar/acicular shape fragments (0.5-1.0 $\mathrm{mm}$ in long dimension) enclosed by albite along with fine-grained pale-green pyroxene $(0.03-0.02 \mathrm{~mm})$, and hence jadeite does not directly contact with the quartz aggregate. However, submicron size quartz grains enclosed in jadeite are identified by EPMA. The majority of pale-green pyroxenes occur near the boundary between the quartz aggregate and the jadeite + albite aggregate, but always in the latter. Some jadeite fragments show the same extinction position. These facts indicate that early stage jadeite decomposed to albite and pale- 


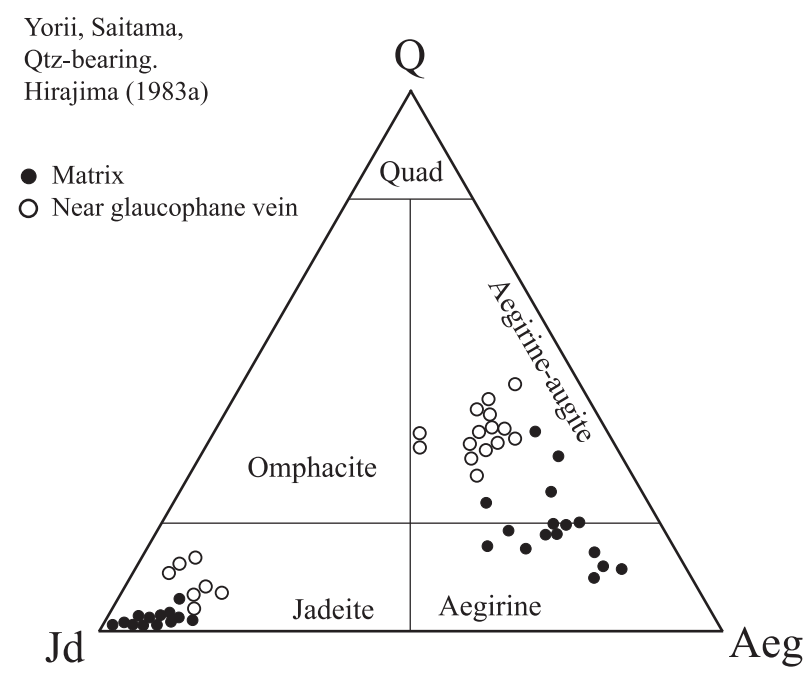

Figure 4. Na-pyroxene compositions in the jadeite + quartz rock in the Yorii area, NE Kanto Mountains (modified from Fig. 4 of Hirajima, 1983a).

green pyroxenes by the following reaction:

$$
\begin{aligned}
& \text { Impure jadeite }+ \text { quartz } \\
& \quad=\text { albite }+ \text { pale-green pyroxenes }
\end{aligned}
$$

Both jadeite $\left(\mathrm{Jd}_{78-84} \mathrm{Aeg}_{6-16} \mathrm{Quad}_{4-14}\right)$ and palegreen pyroxenes $\left(\mathrm{Jd}_{10-30} \mathrm{Aeg}_{35-50} \mathrm{Quad}_{28-45}\right)$ which grow near the glaucophane vein (open circle in Fig. 4; Fig. 4 of Hirajima, 1983a) are slightly richer in Quad content than jadeite $\left(\mathrm{Jd}_{84-99} \mathrm{Aeg}_{1-14} \mathrm{Quad}_{1-4}\right)$ and pale-green pyroxenes $\left(\mathrm{Jd}_{10-30} \mathrm{Aeg}_{50-78} \mathrm{Quad}_{10-35}\right)$ in the grayish-white matrix (solid circle in Fig. 4). The variation of Quad contents in jadeite is obviously inherited in secondary palegreen pyroxenes. This fact also supports the development of the reaction (1) under the mostly closed chemical system from the first higher- $P$ stage characterized by jadeite-quartz equilibrium, to the second moderate- $P$ stage by albite-pale-green pyroxene equilibrium. The Jd content of the secondary pyroxenes are similar with those in Mikabu metabasites of the Kanto Mountains (Hirajima, 1983b). Therefore, Hirajima (1983a) concluded that the formation of the jadeite + quartz assemblage predated the Sanbagawa metamorphism, and the jadeite-bearing leucocratic rock was metamorphosed plagiogranite based on the lack of $\mathrm{K}_{2} \mathrm{O}$-bearing phase and the occurrence of zircon and allanite.

Tsutsumi et al. (2010) reported a SHRIMP U-Pb zircon age of $159 \pm 5 \mathrm{Ma}$ for the jadeite-bearing leucocratic rock. Dated zircon grains show an oscillatory zoning and have high $\mathrm{Th} / \mathrm{U}$ ratio $(0.44-1.35)$, but they reserved the decision on the origin of zircons, whether the igneous origin or the hydrothermal growth.
Fukuyama et al. (2013) also presented the results of $\mathrm{U}-\mathrm{Pb}$ dating and REE analysis of zircons separated from the leucocratic rock. They divided these zircons into two types. Type I zircons are generally euhedral to subhedral crystals, with $0.08-0.50 \mathrm{~mm}$ in size, and show yellow to colorless in appearance. The oscillatory zoning is confirmed in these zircons. Submicron-scale fluid inclusions were also observed at the rim. SHRIMP analyses on Type I zircons yielded an age of $162.2 \pm 0.6 \mathrm{Ma}(\mathrm{n}=21$, MSWD $=1.4$ ), comparable with the previous report of Tsutsumi et al. (2010) within the error. These zircons show typical HREE enriched REE patterns with distinct $\mathrm{Ce}$ and $\mathrm{Eu}$ anomalies, and have $\mathrm{Th} / \mathrm{U}$ rations in the range of $0.50-1.96$.

On the other hand, Type II zircons are mostly subhedral to anhedral and porous, $0.10-0.50 \mathrm{~mm}$ in size, and colorless. No fluid inclusions were observed. Type II zircons showed scattered SHRIMP ages from 159 to 141 $\mathrm{Ma}$. Th/U ratio for these zircons falls in the range of $0.15-$ 1.50. In contrast to Type I zircons, Type II zircons exhibit flatter REE patterns and smaller Ce and Eu anomalies.

Due to the presence of fluid inclusions and solid inclusions of quartz, jadeite and albite in Type I zircon, Fukuyama et al. (2013) interpreted that Type I zircons would have crystallized from a fluid concurrently with other minerals in the jadeite-quartz rock, i.e., 'vein precipitation' origin. Type II zircons are porous and have REE patterns indicative of a hydrothermal zircon. They would have resulted from zircon (re)crystallization after the formation of jadeite-quartz rock in the presence of a fluid phase.

However, Yui and Fukuyama (2015) provided a reinterpretation of Fukuyama et al. (2013) based on new observations obtained from the jadeite-quartz rock. The re-examination of mineral inclusions in zircons clearly showed that these zircons contain mineral inclusions of both primary (igneous, such as biotite, $\mathrm{K}$-feldspar, and hematite) and secondary (metasomatic, such as aegirine-augite, quartz, and albite) origin. The former are not present in the matrix of jadeite-quartz rock and the latter are present in the rock matrix and interpreted as pseudo-inclusions. Yui (2013) proposed that zircons with $\mathrm{Th} / \mathrm{U}>0.1$, Ce anomaly (i.e., $\left.\mathrm{Ce} / \mathrm{Ce}^{*}\right)>10$, Eu anomaly (i.e., $\left.\mathrm{Eu} / \mathrm{Eu}^{*}\right)<0.6$ or $\Sigma \mathrm{REE}>550 \mu \mathrm{g} / \mathrm{g}$ should be considered to be inherited or incompletely recrystallized zircons, and would not be of metasomatic origin, although there remain some against opinions, e.g., Flores et al. (2013). Yui and Fukuyama (2015) pointed out that all Type I zircons of Fukuyama et al. (2013) have Th/U ratios higher than 0.1 and most show $\mathrm{Ce}$ anomaly higher than 10, and then concluded that Type I zircons therefore should not be categorized as metasomatic ones but inher- 
ited, incompletely recrystallized and metasomatic ones. Therefore, the jadeite-quartz rock should have formed through "wholesale metasomatic replacement" process at an age younger than $141 \mathrm{Ma}$ from a protolith of probable igneous origin aged at 162.2 $\pm 0.6 \mathrm{Ma}$.

The investigation on the origin of jadeite using the REE and age data of zircon is a charming methodology. Jadeitite from Itoigawa, Osayama and Nishisonogi areas are free or less in $\mathrm{SiO}_{2}$ phase (e.g., Tsutsumi et al., 2010). However, the Yorii rock contains a significant amount of quartz, so the author of this article does not prefer to call this rock as the jadeitite and he agrees with the conclusion of Yui and Fukuyama (2015). According to the available data cumulated at present, the Yorii rock experienced at least three/four geological events; the first igneous event, zircon crystallization form a magma, jadeite-quartz formation event at high- $P$ metamorphic conditions, and the last albite-aegirine-augite formation event at moderate- $P$ metamorphic conditions. The 'wholesale metasomatic replacement' proposed by Yui and Fukuyama (2015) should take place before or concurrent with the jadeite-quartz formation. At present, the timings of high- $P$ and moderate- $P$ stages are still unknown. Hirajima (1983a, 1983b) pointed out that the pressure condition of the albite-aegirine-augite formation event is comparable to the Mikabu greenstone complex in the Kanto Mountains. If the last thermal event of the the Yorii rock would be concurrent with the Sanbagawa metamorphism, and hence the jadeite-quartz formation should take place before the Sanbagawa metamorphism. The determination of these timings and further zirconology are indispensable to understand the formation process of the Yorii rock and the systematics of high-field-strength elements in the subduction zone as pointed out by Fukuyama et al. (2013).

\section{Jadeite-bearing rocks in the Chubu district of the Sanbagawa belt}

Seki (1960) and Seki et al. (1960) reported the occurrence of jadeite from meta-gabbroic rocks surrounded by serpentinite in the Shibukawa district, Shizuoka Prefecture, central Japan, using XRD method. Note that they could not show the close association of jadeite and quartz. Watanabe (1977) obtained only one available chemical analysis of impure jadeite $\left(\mathrm{Jd}_{83} \mathrm{Aeg}_{13} \mathrm{Quad}_{4}\right)$ from a meta-gabbro embedded in serpentinite in the Shibukawa district, but he also could not find jadeite grains in contact with quartz. Instead, Watanabe $(1975,1977)$ pointed out that lower jadeitic $\mathrm{Na}$-pyroxene $\left(\mathrm{Jd}_{<20}\right)$ were common in the lower grade metamorphic rocks in the Oshika district, Nagano Prefecture. Therefore, even if jadeite grains reported by Seki (1960) and Seki et al. (1960) do not coexist with quartz, they can be formed by the Sanbagawa metamorphism under the albite stable condition (Fig. 3).

\section{Jadeite-bearing rocks in the Shikoku Island of the Sanbagawa belt}

Jadeite-quartz association is one of the diagnostic mineral assemblages of the eclogite facies, but its occurrence is limited in Ca-poor variety of the host rock, such as granitic rocks, greywackes and charts, although omphacite is major clinopyroxene in mafic rocks under the eclogite facies conditions (e.g., Ernst, 1971; Hirajima et al., 1988). The eclogite facies rocks of the Sanbagawa belt are mainly exposed in the Besshi area of the central Shikoku, and Kotsu and Bizan areas of the eastern Shikoku, but $\mathrm{Na}^{-}$ pyroxenes with lower jadeite contents are reported from quartz schists in the relevant areas (e.g., Enami et al., 1994; Ubukawa et al., 2007).

Recently, jadeite grains with or without quartz have been identified as tiny inclusions in garnets of the eclogite facies rocks in the Besshi area (Endo and Tsuboi, 2013) and Bizan area (Kabir and Takasu, 2016), and in a composite-zoned garnet of a metapelite of the Asemigawa area (Taguchi and Enami, 2014), one after another.

Endo and Tsuboi (2013) found jadeite inclusions $(<10 \mu \mathrm{m})$ along with omphacite, kyanite, quartz and rutile in $\mathrm{Mg}$-rich rim of garnet grains of a massive metagabbro, which shows the peak $P-T$ conditions of $\sim 2.5$ $\mathrm{GPa}$ and $570{ }^{\circ} \mathrm{C}$, in the eastern Iratsu body. The sample is mainly composed of garnet, omphacite, kyanite, quartz, phengite, epidote, albite, amphibole, and apatite in the well equilibrated domain and the former igneous/granulitic clinopyroxene domains. Clinopyroxene shows the three mode of occurrence; i) inclusion in garnet, ii) a major constituent phase in the matrix and iii) relict igneous/ granulitic clinopyroxene (Fig. 5).

Most clinopyroxene inclusions are omphacite $\left(\mathrm{Jd}_{37-51} \mathrm{Aeg}_{6-19} \mathrm{Quad}_{40-50}\right)$ but impure jadeite and jadeiterich omphacite $\left(\mathrm{Jd}_{64-80} \mathrm{Aeg}_{0-11} \mathrm{Quad}_{13-33}\right)$ are also present. The latter group pyroxenes occur as tiny $(<10 \mu \mathrm{m}$ across $)$ discrete grains or composite grains with jadeite and omphacite. For the case of the inclusion pair of omphacite and jadeite, the omphacite grains are generally richer in aegirine component than the jadeite grains (Fig. 5).

$P-T$ pseudosection modellings for MORB suggest that the stability field of jadeite does not appear in the eclogite facies meta-MORB (e.g., Diener and Powell, 2012 and references therein). However, Endo and Tsuboi (2013) attributed the occurrence of impure jadeite to the the attainment of $\mathrm{Na}$ - and Al-rich effective bulk composition due to the persistence of relict igneous/granulitic clinopyroxene and a bit lower $\mathrm{H}_{2} \mathrm{O}$ activity than the para- 
Eastern Iratsu, Ehime,

Eclogite facies,

Endo \& Tsuboi (2013)

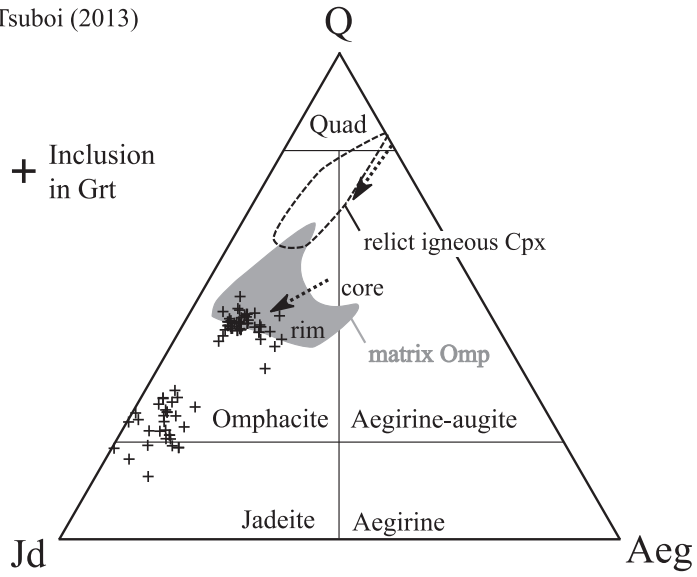

Figure 5. Pyroxene compositions in a massive metagabbro, which suffered eclogite facies metamorphism with the peak $P-T$ conditions of $\sim 2.5 \mathrm{GPa}$ and $570{ }^{\circ} \mathrm{C}$, in the eastern Iratsu body, central Shikoku (modified from Fig. 4 of Endo and Tsuboi, 2013). More detail refers the text.

gonite-bearing eclogite. They considered the heating of the early stage of the exhumation enhanced the transformation of jadeite to omphacite in the rock matrix.

Kabir and Takasu (2016) also found jadeite grains as inclusion in the garnet showing the prograde zoning from garnet-glaucophane schists, of which peak-PT conditions are $580-600{ }^{\circ} \mathrm{C}$ and $18-20 \mathrm{kbar}$, in the Bizan area. Jadeite grains occur as tiny anhedral discrete inclusions $(<0.03$ $\mathrm{mm}$ across) or as polyphase inclusions along with glaucophane or quartz. Jadeite contents of the clinopyroxene inclusions in garnet gradually increase from the core $\left(\mathrm{Jd}_{46-64}\right)$, to the mantle and the $\operatorname{rim}\left(\mathrm{Jd}_{65-75}\right)$ with almost constant quadrilateral pyroxene content (Quad) (namely Quad $_{1-12}$ ) (Fig. 6). Their pseudosection calculation suggests the occurrence of the jadeitic clinopyroxene in their sample is strongly ascribed to the low $\mathrm{CaO}(4.4-4.5 \mathrm{wt} \%)$ and $\mathrm{MgO}(2.1-2.3 \mathrm{wt} \%)$ of the host rock.

Taguchi and Enami (2014) found jadeite and quartz inclusions from an inner segment of a composite-zoned garnet from a metapelite in the southern albite-biotite zone of the Asemigawa area, located about $15 \mathrm{~km}$ ESE of the Besshi area. The jadeite $\left(\mathrm{Jd}_{92}\right)$-quartz assemblage gives $1.4-1.9 \mathrm{GPa}$ at $500-700{ }^{\circ} \mathrm{C}$ as the minimum- $P$ for their formation, which beyond the estimated pressure of the relevant area. They also reported that the measured residual pressure of quartz grains included in garnet shows the similar value to those of the eclogite unit of the Besshi area. Based on these data, they pointed out that a part of the southern albite-biotite zone once suffered the eclogite facies metamorphism.

Jadeite not associated with quartz is found from
Bizan, Tokushima,

Eclogite facies,

Kabir \& Takasu (2016)

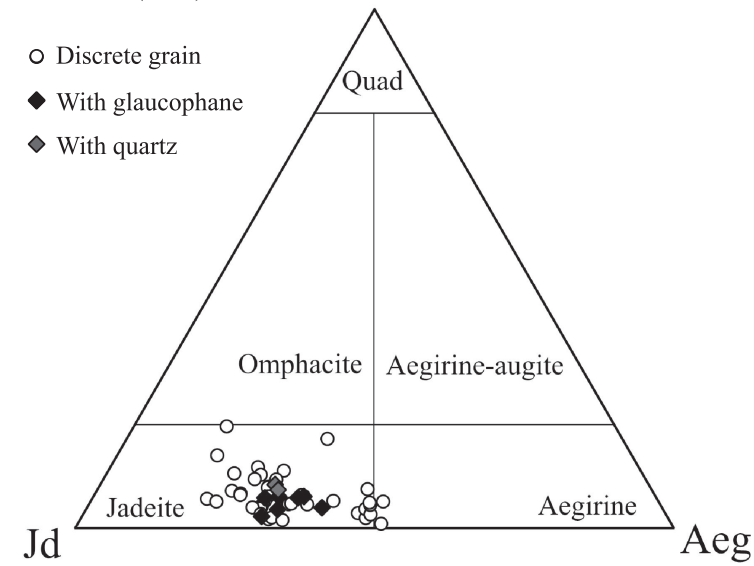

Figure 6. Na-pyroxene compositions in a metapelite, which suffered eclogite facies metamorphism with the peak $P-T$ conditions of $580-600{ }^{\circ} \mathrm{C}$ and $1.8-2.0 \mathrm{GPa}$ in the Bizan area, eastern Shikoku (modified from Fig. 9a of Kabir and Takasu, 2016).

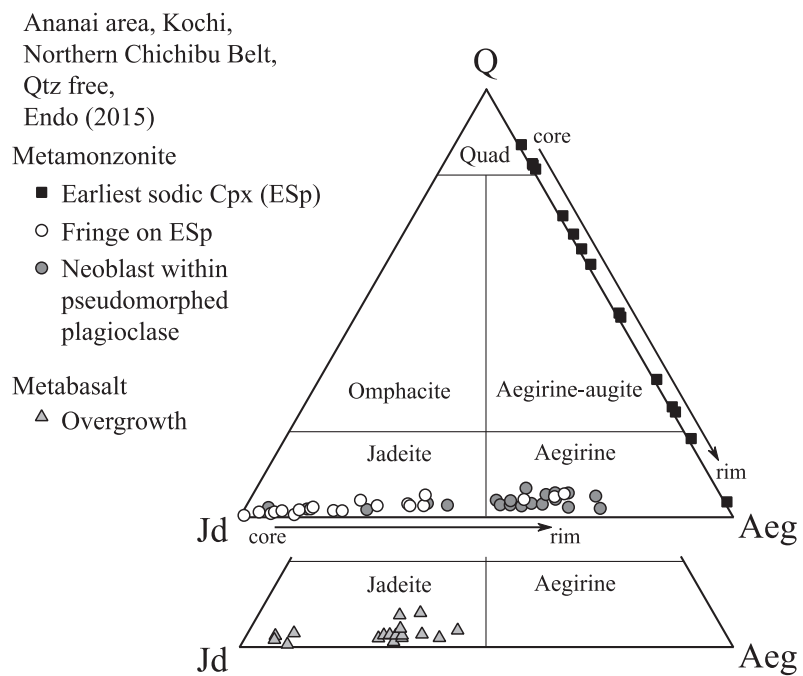

Figure 7. Na-pyroxene compositions in metabasalt and metamonzonite with alkaline affinity from Ananai area in the the Northern Chichibu belt in central Shikoku (modified from Fig. 4 of Endo, 2015).

Northern Chichibu meta-basaltic rock with alkaline affinity in the central Shikoku (Fig. 7) and its formation was explained by the reaction analcime $=$ jadeite $+\mathrm{H}_{2} \mathrm{O}$ (Endo, 2015). Such kind of jadeite is stable at 0.6-0.7 GPa at $300{ }^{\circ} \mathrm{C}$ (Fig. 3), and its formation was ascribed to the lowest grade of the Sanbagawa metamorphism.

\section{Jadeite-bearing rocks in the Kamuikotan belt, Hokkaido}

The Kamuikotan belt runs north to south along the axis of 
the Hokkaido more than $300 \mathrm{~km}$ with a maximum width of $30 \mathrm{~km}$ (Fig. 1). The belt is mainly composed of $\mathrm{H} P$ type metamorphic rocks and LP type ones. The Horokanai ophiolite belongs to the latter and it overlies the $\mathrm{H} P$ type metamorphic rocks (e.g., Asahina and Komatsu, 1979; Ueda, 2010). Available geochronological data mainly of $\mathrm{K}-\mathrm{Ar}$ and $\mathrm{Ar}-\mathrm{Ar}$ phengite extracted from $\mathrm{HP}$ type metamorphic rocks show Cretaceous metamorphic timings but those data diversely scatter from 135 to 45 Ma (Shibakusa and Itaya, 1992; Ota et al., 1993; Iwasaki et al., 1995). The HP type metamorphic rocks are mainly composed of the coherent unit, exotic blocks and serpentinite mélange zone (e.g., Ueda, 2010). There still arguments on the metamorphic zonal mapping and the special extent of each coherent unit, and on their development history, along with the origin of exotic blocks, among the different researcher groups. This article does not treat these issues but do the description of jadeite-bearing rocks.

The identification jadeite in this belt was initially done by the XRD method by Seki and Shido (1959) and Shido and Seki (1959) as well as the case both in the Kanto Mountains and the central Japan. Gouchi (1983) reported the first identification of jadeite associated with quartz in metabasic/metapelitic rocks using EPMA. He proposed that the studied rocks experienced two stage metamorphisms, such as the first higher- $P$ metamorphism $(>1 \mathrm{GPa})$ represented by the clinopyroxene core with higher jadeite contents $\left(\mathrm{Jd}_{>90}\right)$ along with lawsonite and $\mathrm{Na}$-amphibole with/without stilpnomelane and pumpellyite, and the subsequent lower- $P$ type metamorphism represented by the clinopyroxene rim with omphacite composition $\left(\mathrm{Jd}_{<60}\right)$.

Takayama (1986) found jadeite associated with quartz in pelitic rocks and metaplagiogranites in the gorge area. However, such rock-types never occur as a part of the coherent metamorphic sequence, but are found only as exotic blocks enclosed in serpentinite. The serpentinite matrix may carry jadeite + quartz-bearing metapelites and metaplagiogranites into the coherent metamorphic sequence, which suffered the lawsonite-albite facies metamorphism (Fig. 3).

Osada et al. (2007) find jadeite $\left(\mathrm{Jd}_{>95}\right)$-quartz-Kfeldspar assemblage from metagranitoids, which occur as boulder size river floats in and around the serpentinite in the gorge area. They also proposed a $P-T$ history similar to Takayama (1986).

Shibakusa and Hirajima (1988) reported that jadeite contents of $\mathrm{Na}$-pyroxenes in contact with quartz and albite vary from 0.56 to 0.74 in metabasites of the coherent unit in the Horokanai-Kamietanbetsu area and pointed out that the coherent unit of the Kamuikotan HP type metamorphic rocks was formed under albite stability field.

Thus, these four papers published after 1980's attained the same conclusion that jadeite-quartz bearing rocks occur only as tectonic blocks trapped in serpentinite. It is noteworthy that two articles pointed out that protolith of the jadeite-quartz bearing rocks is granitic rocks, as well as the case of the Yorii area in the Kanto Mountains. The future application of zirconology to these rocks will give a new light for understanding both the development history of the Kamuikotan belt and the deep fluid activity in the subduction zone in NE Japanese Islands.

\section{EPILOGUE}

The first breakthrough of the finding of jadeite in Japanese metamorphic rocks is mainly led by Dr. Yotaro Seki and his coworkers in the 1960's using the XRD method. Some of their result was cited in the famous text books of Miyashiro $(1965,1973)$, as the metamorphic pressure of the Kanto Mountains in the Sanbagawa belt is higher than the rest of the belt. The development of EPMA-based studies since the 1970's causes its second breakthrough in the 1980's. Works of this period done in the Kanto Mountains reveal that the Sanbagawa metamorphic rocks were formed under albite stability field and jadeitic pyroxene can occur in quartz free rocks (Tanabe et al., 1982; Hirajima, 1983a, 1983b). Probably now it would be reaching a new movement, as the jadeite + quartz assemblages are accidentally found throughout so-called 'inclusion mineralogy' in the eclogitic garnet in the Shikoku area (Endo and Tsuboi, 2013; Taguchi and Enami, 2014; Kabir and Takasu, 2016). The movement has a great potential to determine the areal extent of the eclogite unit in the Sanbagawa belt.

The jadeite-quartz rocks found from the Yorii area and the Kamuikotan gorge are interpreted as the tectonic block against the surrounding metamorphic rocks, but formation timings of the jadeite + quartz assemblage are still unknown.

Thus far, zirconology was applied only to the Yorii sample at present. The expansion of this study to other rocks in Japanese Island will unravel the developing history of the deeply subducted rocks.

\section{ACKNOWLEDGMENTS}

The author is greatly appreciated for the constructive comments from R. Miyawaki and T. Tsujimori. This study is partly supported by JSPS KAKENHI, Grant No. JP25257208. 


\section{REFERENCES}

Aoki, K., Maruyama, S., Isozaki, Y., Otoh, S. and Yanai, S. (2011). Recognition of the Shimanto HP metamorphic belt within the traditional Sanbagawa HP metamorphic belt: new perspectives of the Cretaceous-Paleogene tectonics in Japan. Journal of Asian Earth Science, 42, 355-369.

Aoya, M. (2001) $P-T-D$ path of eclogite from the Sambagawa belt deduced from combination of petrological and microstructural analyses. Journal of Petrology, 42, 1225-1248.

Arai, H., Miyashita, A., Tanabe, K. and Murata, M. (2011) Petrological and mineralogical characterizations of jadeite-bearing rocks form the Mikabu greenstones in the Shimonita area, Kanto Mountains, Central Japan. Japanese Magazine of Mineralogical and Petrological Sciences, 40, 177-194 (in Japanese with English abstract).

Asahina, T. and Komatsu, M. (1979) The Horokanai ophiolitic complex in the Kamuikotan tectonic belt, Hokkaido, Japan. Journal of geological Society of Japan, 85, 317-330.

Banno, S. and Sakai, C. (1989) Geology and metamorphic evolution of the Sambagawa Belt, Japan. In: Evolution of Metamorphic Belts, eds. by Daly, JS. Cliff, RA. \& Yardley, BWD., Geological Society Special Publication, 43, 519-532

Diener, J.F.A. and Powell, R. (2012) Revised activity-composition models for clinopyroxene and amphibole. Journal of Metamorphic Geology, 30, 113-234.

Enami, M. (1983) Petrology of pelitic schists in the oligoclasebiotite zone of the Sanbagawa metamorphic terrain, Japan: phase equilibria in the highest grade zone of a high-pressure intermediate type of metamorphic belt. Journal of metamorphic Petrology, 1, 141-161

Enami, M., Wallis, S.R. and Banno, Y. (1994) Paragenesis of sodic pyroxene-bearing quartz schist: implications for the PT history of the Sanbagawa belt. Contributions to Mineralogy and Petrology, 116, 182-198.

Endo, S. (2015) Jadeite-bearing metaigneous rocks from the Northern Chichibu belt, SW Japan: implications for the lowest-grade Sanbagawa metamorphism. Journal of Mineralogical and Petrological Sciences, 110, 8-19.

Endo, S. and Tsuboi, M. (2013) Petrogenesis and implications of jadeite-bearing kyanite eclogite from the Sanbagawa belt (SW Japan). Journal of Metamorphic Geology, 31, 647-661.

Ernst, W.G. (1971) Petrological reconnaissance of Franciscan metagraywackes from the Diablo Range. Journal of Petrology, 12, 413-437.

Flores, K.E., Martens, U.C., Harlow, G.E., Brueckner, H.K. and Pearson, N.J. (2013) Jadeitite formed during subduction: in situ zircon geochronology constraints from two different tectonic events within the Guatemala suture zone. Earth and Planetary Science Letter, 371-372, 67-81.

Fukuyama, M., Ogasawara, M., Horie, K. and Lee, D.C. (2013) Genesis of jadeite-quartz rocks in the Yorii area of the Kanto Mountains, Japan. Journal Asian Earth Science. 63, 206-217.

Gouchi, N. (1983) Kamuikotan metamorphic rocks in the Kamuikotan gorge area, west of Asahikawa, Hokkaido. The Journal of the Japanese Association of Mineralogists, Petrologists and Economic Geologists, 78, 383-393 (in Japanese with English abstract).

Hacker, B.R., Abers, G.A. and Peacock, S.M. (2003) Subduction factory 1: theoretical mineralogy, densities, seismic wave speeds, and $\mathrm{H}_{2} \mathrm{O}$ content. Journal of Geophysical Research,
108, 2029, doi:10.1029/2001JB001127.

Harlow, G.E., Tsujimori, T. and Sorensen, S.S. (2015). Jadeitites and plate tectonics. Annual Review of Earth and Planetary Science. http://dx.doi.org/10.1146/annurer-earth-060614-105215.

Hashimoto, M. (1964) Omphacite veins in metadiabase from Asahine in the Kanto Mountains, Japan. Proceedings of Japan Academy, 40, 31-35.

Hayashi, M., Yasui, M. and Yamazaki, A. (2013) Urgent report on natural monuments: Jewels and minerals in the Saitama Prefecture. Abstract of the Heisei 25 annual meeting of the Gemmological Society of Japan. http://doi.org/10.14915/gsj. 35.0.10.

Higashino, T. (1990) The higher grade metamorphic zonation of the Sambagawa metamorphic belt in central Shikoku, Japan. Journal of Metamorphic Geology, 8, 413-423.

Hirajima, T. (1983a) Jadeite + quarts rock from the Kanto Mountains. The Journal of the Japanese Association of Mineralogists, Petrologists and Economic Geologists, 78, 77-83.

Hirajima, T. (1983b) The analysis of the paragenesis of glaucophanitic metamorphism for a model ACF system by SCHREINEMAKERS' method. Journal of Geological Society of Japan, 89, 679-691 (in Japanese with English abstract).

Hirajima, T., Banno, S., Hiroi, Y. and Ohta, Y. (1988) Phase petrology of eclogites and related rocks from the Motalafjella high-pressure metamorphic complex in Spitsbergen and its significance. Lithos, 22, 75-97.

Hirajima, T., Isono, T. and Itaya, T. (1992) K-Ar age and chemistry of white mica in the Sanbagawa metamorphic rocks in the Kanto Mountains, central Japan. Journal of Geological Society of Japan, 98, 445-455 (in Japanese with English abstract).

Holland, T.J.B. and Powell, R. (1998) An internally consistent thermodynamic data set for phases of petrological interest. Journal of Metamorphic Geology, 16, 309-343.

Itaya, T., Tsujimori, T. and Liou, J.G. (2011) Evolution of the Sanbagawa and Shimanto high-pressure belts in SW Japan: insights from $\mathrm{K}-\mathrm{Ar}$ (A-Ar) geochronology. Journal of Asian Earth Science, 42, 1075-1090.

Iwasaki, I., Watanabe, T., Itaya, T., Yamazaki, M. and Takigami, Y., (1995) Palaeogene K-Ar ages from the Kamuikotan metamorphic rocks, southern area of the Kamuikotan Gorge, central Hokkaido, northern Japan. Geological Journal, 30, 281295.

Kabir, M.F. and Takasu, A. (2016) Jadeite-garnet glaucophane schists in the Bizan area, Sambagawa metamorphic belt, eastern Shikoku, Japan: significance and extent of eclogite facies metamorphism. Journal of Metamorphic Geology, 34, 893916.

Kunugiza, K., Takasu, A. and Banno, S. (1986) The origin and metamorphic history of the ultramafic and metagabbro bodies in the Sanbagawa metamorphic belt. Geological Society of America, Memoir, 164, 375-385.

Kurata, H. and Banno, S. (1974) Low-grade progressive metamorphism of pelitic schists of the Sazare area, Sanbagawa metamorphic terrain in central Shikoku, Japan. Journal of Petrology, 15, 361-382.

Liou, J.G. (1971a) P-T stabilities of laumontite, wairakite, lawsonite and related minerals in the system $\mathrm{CaAl}_{2} \mathrm{Si}_{2} \mathrm{O}_{8}-\mathrm{SiO}_{2}-\mathrm{H}_{2} \mathrm{O}$. Journal of Petrology, 12, 379-411.

Liou, J.G. (1971b) Stilbite-laumontite equilibria. Contribution to Mineralogy and Petrology, 31, 171-177.

Matsuoka, A., Yamakita, S., Sakakibara, M. and Hisada, K. (1998) Unit division for the Chichibu Composite belt Belt from a 
view point of accretionary tectonics and geology of western Shikoku, Japan. Jouronal of Geological Soceity of Japan, 104, 634-653 (In Japanese with English abstract).

Miyashiro, A. (1965) Metamorphic rocks and Metamorphic Belts. (In Japanese). pp. 458, Iwanami, Tokyo.

Miyashiro, A. (1973) Metamorphism and Metamorphic Belts. pp. 492, George Allen and Unwin, London.

Miyashita, A. and Itaya, T. (2002) K-Ar Age and Chemistry of Phengite from the Sanbagawa Schists in the Kanto Mountains, Central Japan, and their Implication for Exhumation Tectonics. Gondwana Research, 5, 837-848.

Nakajima, T., Banno, S. and Suzuki, T. (1977) Reaction leading to the disappearance of pumpellyite in law-grade metamorphic rocks of the Sanbagawa metamorphic belt in central Shikoku, Japan. Journal of Petrology, 18, 263-284.

Nitsch, K.H. (1968) Die Stabilität von Lawsonit. Naturwissenschaften, 55, 388.

Osada, Y., Maekawa, H. and Yamamoto, K. (2007) Jadeite-quartz$\mathrm{K}$-feldspar rocks in the Kamuikotan zone, Japan. Journal of Mineralogical and Petrological Sciences, 102, 50-56.

Ota, T., Sakakibara, M. and Itaya, T. (1993) K-Ar ages of the Kamuikotan metamorphic rocks in Hokkaido, Japan. Journal of Geological Society of Japan, 99, 335-345 (in Japanese with English abstract).

Otsuki, M. and Banno, S. (1990) Prograde and retrograde metamorphism of hematite-bearing basic schists in the Sanbagawa belt in central Shikoku. Journal of Metamorphic Geology, 8, 425-439.

Sakurai, K. and Nagashima, O. (1957) Minerals from the Chichibu district (part 2). Bulletin of Chichibu Natural Museum, 7, 3561 (in Japanese).

Seki, Y. (1958) Glaucophanitic Regional Metamorphism in the Kanto Mountains, central Japan. Japanese Journal of Geology and Geography, 29, 233-258.

Seki, Y. (1960) Jadeite in Sambagawa crystalline schists of central Japan. American Journal of Science, 258, 705-715.

Seki, Y. (1961) Notes on rock-forming minerals (17), Jadeite from Kanasaki (Kanagasaki) of the Kanto Mountains, central Japan. Journal of Geological Society of Japan, 67, 101-104.

Seki, Y. (1965) Jadeitic pyroxenes found as pebbles in lower Cretaceous formation of the Kanto Mountains, central Japan. The Journal of the Japananese Association of Mineralogists, Petrologists and Economic Geologists, 53, 165-168.

Seki, Y. and Shido, F. (1959) Discovery of of jadeite from the Sanbagawa and Kamuikotan metamorphic belts. Proceedings of Japan Academy, 35, 137-138.

Seki, Y., Aiba, M. and Kato, C. (1960) Jadeite and associated minerals of meta-gabbroic rocks in the Shibukawa district, central Japan. American Mineralogist, 45, 668-679.

Shibakusa, H. and Hirajima, T. (1988) Jadeite from the HorokanaiKamietanbetsu area of the Kamuikotan zone, Hokkaido, Japan. Journal of Mineralogy, Petrology and Economic Geology, 83, 507-513.

Shibakusa, H. and Itaya, T. (1992) K-Ar ages of glaucophane schists and associated rocks from the Horokanai-Kamietanbetsu area in the Kamuikotan zone, Hokkaido, northern Japan. Journal of Geological Society of Japan, 98, 1061-1064.

Shido, F. and Seki, Y. (1959) Notes on Rock-Forming Minerals (11) jdeite and Hornblende from the Kamuikotan Metamorohci belt. Journal of Geological Society of Japan, 65, 673-677.

Suzuki, S. and Ishizuka, H. (1998) Low-grade metamorphism of the Mikabu and northern Chichibu belts in central Shikoku,
SW Japan: implications for the areal extent of the Sanbagawa low-grade metamorphism. Journal metamorphic Geology, 16, 107-116.

Takayama, M. (1986) Mode of occurrence and significance of jadeite in the Kamuikotan metamorphic rocks, Hokkaido, Japan. Journal of Metamorphic Geology, 4, 445-454.

Taguchi, T. and Enami, M. (2014) Coexistence of jadeite and quartz in garnet of the Sanbagawa metapelite from the Asemi-gawa region, central Shikoku, Japan. Journal of Mineralogical and Petrological Sciences, 109, 169-176.

Tanabe, K., Tomioka, N. and Kanehira, K. (1982) Jadeite-aragonite bearing rocks from the Sanbagawa metamorphic terrane. Proceedings of Japan Academy, 58, 199-203.

Tsujimori, T. and Harlow, G.E. (2012) Petrogenetic relationships between jadeitite and associated high-pressure and low-temperature metamorphic rocks in worldwide jadeitite localities: a review. European Journal of Mineralogy, 24, 371-390.

Tsutsumi, Y., Miyashita, A., Terada, K. and Hidaka, H. (2009) SHRIMP U-Pb dating of detrital zircons from the Sanbagawa Belt, Kanto Mountains, Japan: need to revise the framework of the belt. Journal of Mineralogical and Petrological Sciences, 104, 12-24.

Tsutsumi, Y., Yokayama, K., Miyawaki, R., Matsubara, S., Terada, K. and Hidaka, H. (2010) Ages of zircons in jadeitite and jadeite-bearing rocks of Japanese islands. Bulletin of National Museum Natural Science, Ser. C, 36, 19-30.

Ueda, H. (2010) The Kamuikotan belt. In Geology of Hokkaido, Series of Japanese Geology (the Geological Society of Japan Ed.). Asakura Publishing Co., Ltd., Tokyo, 40-48 (in Japanese).

Ubukawa, T., Hatanaka, A., Matsumoto, K. and Hirajima, T. (2007) Pseudosection analysis for talc-Na pyroxene-bearing piemontite quartz schist in the Sanbagawa belt, Japan. Island Arc, 16, 553-574.

Wallis, S.R. and Aoya, M. (2000) A re-evaluation of eclogite facies metamorphism in SW Japan: proposal for an eclogite nappe. Journal of Metamorphic Geology, 18, 653-664.

Watanabe, T. (1975) Aegirine-Augite and Sodic Augite from the Sambagawa and the Chichibu Belts in the Oshika District, Central Japan, with Special Reference to Na-Metasomatism. Journal of the Faculty of Science, Hokkaido University. Series 4, Geology and Mineralogy, 16, 519-532.

Watanabe, T. (1977) Metamorphism of the Sambagawa and Chichibu Belts in the Oshika District, Nagano Prefecture, Central Japan. Journal of the Faculty of Science, Hokkaido University, Series 4, Geology and Mineralogy, 17, 629-694

Yui, T.F., Maki, K., Usuki, T., Lan, C.Y., Martens, U., Wu, C.M., Wu, T.W. and Liou, J.G. (2010) Genesis of Guat, emala jadeitite and related fluid characteristics: insight from zircon. Chemical Geology, 270, 45-55.

Yui, T.F. (2013) The genesis of jadeitite: a viewpoint from zirconology. The Goldschmidt Conference 2013, Florence, Italy. Abstract, 2572.

Yui, T.F. and Fukuyama, M. (2015) A revisit to the Yorii jadeitequartz rock, the Kanto Mountains, central Japan: Implications for petrogenesis. Journal of Asian Earth Sciences, 108, 58-67.

Manuscript received April 9, 2017

Manuscript accepted July 26, 2017

Published online September 22, 2017

Manuscript handled by Ritsuro Miyawaki Guest Editor 